\title{
Nitrogen recovery from fertilizers and cover crops by maize crop under no-tillage system
}

\author{
Edson Cabral da Silva ${ }^{1}$, Takashi Muraoka ${ }^{2}$, Alefe Viana Souza Bastos ${ }^{* 1}$, Vinícius Ide Franzini ${ }^{3}$, Alinne da \\ Silva $^{2}$, Salatiér Buzetti ${ }^{4}$, Karuppan Sakadevan ${ }^{5}$, Frederico Antonio Loureiro Soares ${ }^{1}$, Marconi Batista \\ Teixeira ${ }^{1}$, Paulo César Ocheuze Trivelin ${ }^{2}$ and Leandro Coelho de Araújo ${ }^{4}$
}

\author{
${ }^{1}$ Instituto Federal Goiano - Rio Verde, GO, Brasil \\ ${ }^{2}$ Universidade de São Paulo, Centro de Energia Nuclear na Agricultura - Piracicaba, SP, Brasil \\ ${ }^{3}$ Embrapa Cocais - São Luís - MA, Brasil \\ "Universidade Estadual Paulista "Júlio de Mesquita Filho" (FEIS/UNESP) - Ilha Solteira, SP, Brasil \\ ${ }^{5}$ Soil and Water management \& Crop Nutrition Subprogram, Joint FAO/IAEA Division of Nuclear Techniques in Food \\ and Agriculture, International Atomic Energy Agency, IAEA, Vienna, Austria
}

\section{*Corresponding author: alefe_viana@hotmail.com}

Abstract

Crop rotation associated with the use of cover crops promotes the introduction of crop residues to the soil, with direct and indirect effects on the availability of plant nutrients, especially nitrogen $(\mathrm{N})$. The objectives of this study were to estimate the $\mathrm{N}$ utilization from ${ }^{15} \mathrm{~N}$-urea and cover crop residues (labelled with ${ }^{15} \mathrm{~N}$ ) of maize crops grown in succession, and evaluate the effects of the isolated and combined use of cover crops and urea on maize plant height, yield components, and grain yield, grown under a notillage system. Field research was conducted in an Oxisol (Rhodic Haplustox), Cerrado (Savannah) phase. The experimental design was a randomized block with 20 treatments and four replications in a $5 \times 4$ factorial scheme. The treatments were four cover crops species: sunn hemp (Crotalaria juncea L.), pigeon pea (Cajanus cajan (L.) Millsp), green velvet bean (Mucuna prurens), and millet (Pennisetum glaucum L.) + spontaneous vegetation (fallow in the off-season), combined with four $\mathrm{N}$ rates: $0,30,90$, and 150 kg ha 1 , applied at the sowing and topdressing stages. The results showed that legume cover crops provided maize grain yields equivalent to the application of $80-108 \mathrm{~kg} \mathrm{ha}^{-1} \mathrm{~N}$ as urea. The urea $\mathrm{N}$ utilization by the maize was at an average of $43.5 \%$ of the applied amount. The results indicate that cover crops, particularly legume cover crops, are an important source of $\mathrm{N}$ to non-legume cereals. Legumes used as cover crops can replace nitrogen fertilizers of more than $80 \mathrm{~kg}$ ha, which is both environmentally and economically viable for corn production.

Keywords: Zea mays, green manure, urea, isotope dilution, Oxisol, Savannah.

\section{Introduction}

Maize has great social and economic importance worldwide, especially in Brazil. It is one of the most cultivated grains in the world by the multiplicity of applications in human consumption, animal feed, biofuel, and several other industrial uses (Ranum et al., 2014). With 15.12 million hectares of cropped area occupied by maize, Brazil is now a strategic country for maize production and is the world's second largest maize exporter (CONAB, 2015), whose export volume comprises about a third of all global production (ANEC, 2013). However, during the 2014/2015 harvest, the national average maize yield was $5.382 \mathrm{~kg} \mathrm{ha}^{-1}$, which was considered low compared to countries such as the United States with $9.970 \mathrm{~kg} \mathrm{ha}^{-1}$ (USDA, 2015). This can occur in Brazil because the maize is grown in various regions with different soil and climatic conditions, ranging from subsistence farming to large crops with high agricultural technologies with different cropping systems and purposes (Embrapa, 2006). Today, in Brazil, it is common to find farmers with an average grain yield in excess of $10.000 \mathrm{~kg}$ $\mathrm{ha}^{-1}$, which is due to the use of new technologies, especially with respect to the management of soil fertility and development of improved maize varieties with superior genetics.

In the Savannas of Central Brazil, or the Brazilian Cerrado, the dominant soils are Latosols (Oxisols). No-tillage cropping systems were introduced to these areas in the mid-1980s. While no-tillage has the advantage of reducing soil degradation and increasing soil organic carbon, total nitrogen, and microbial biomass (Machado and Silva, 2001; Ngwira et al., 2012; Carvalho et al., 2014), which are the fundamental components of soil fertility, the use of cover crops for rotation helps improve soil fertility and nutrient availability. However, the use of cover crops for improving soil fertility in these systems has rarely been studied. Brazil is one of the countries that have increased no-tillage agricultural area. Since the 2011/2012 growing season, of 
the 32 million hectares under no-till management area in Brazil approximately a third have been located on Cerrado soil (FEBRAPDP, 2018). This corresponds to more than half of the country's cropped area. The expansion of no-tillage systems associated with the use of cover crops is encouraged by the federal government, due to its environmental benefits related to the mitigation of greenhouse gases and carbon sequestration.

No-tillage has some basic requirements, which comprises producing straw and crop rotation (Carvalho et al., 2015). Maize is one of the main crops managed under the no-tillage system in Brazil, which is grown mainly in the Savannah area in rotation and/or succession with soybean or cotton crops. It has been an important crop for the consolidation of notillage systems in Brazil because of the large straw contribution to soil with high $\mathrm{C} / \mathrm{N}$ ratios. The non-plowing of the soil allied to the addition of organic carbon through the cultivation of cover crops and/or "commercial" crops, which add great amounts of residues to the soil, is fundamental for maintaining the balance of organic matter, which is an important $\mathrm{N}$ source for the crops (Amado et al., 2002; Scivittaro et al., 2003; Carvalho et al., 2014).

The systematic use and management of cover crops, associated with the rotation and succession of diverse crops for use in no-tillage systems in the Cerrado, is a strategy for trash (mulch/crop residues) accumulation on the soil surface (Carvalho et al., 2015). Cover crops play an important role in no-tillage management, including protecting the soil from erosion, increasing soil organic matter, improving chemical, physical, and biological quality, and promoting carbon sequestration, which allows producers to reduce costs on fertilizers and herbicides for weed control (Carvalho et al., 2011; Rosa et al., 2012; Rosolem and Calonego, 2013; Carvalho et al., 2014). Although the amount of crop residues added to no-tillage systems in the Cerrado region of Brazil is generally relatively low, replacing the bare fallow period with a cover crop can result increases in both $\mathrm{N}$ uptake and the grain yield of subsequent maize crops (Maltas et al., 2009).

Nitrogen is the most important nutrient in terms of influencing maize yield, and is required in large quantities. It is also the main factor that burdens the cost of production of such a crop. Another aspect to be considered concerning the $\mathrm{N}$ fertilization of maize is the source of mineral $\mathrm{N}$ (Amado et al., 2002; Silva et al., 2006a). The use of cover crops, along with mineral fertilization and maintenance of straw over the soil, can increase the stocks of organic $\mathrm{N}$ in the soil (Sainju et al., 2005; Carvalho et al., 2014). Several legumes have been investigated for their rates of $\mathrm{N}$ fixation and subsequent contribution of $\mathrm{N}$ in maize (Carvalho et al., 2015). The legumes cover crops due to their ability to fix $\mathrm{N}_{2}$ and take up residual soil $\mathrm{N}$ in the early fall following a summer cash crop. Cover crops are essential in highly weathered soils such as Oxisols, in which cation exchange capacity is highly dependent on soil organic matter (Amado et al., 2002). In these conditions, liming and fertilization are usually not enough to reach profitable crop yields (Silva et al., 2007; Carvalho et al., 2011). The importance of utilizing cover crops has increased recently because it is an important strategy to maintain or improve soil fertility for the sustainable intensification of crop production (Carvalho et al., 2015).

The availability of nutrients from crop residues is related their $\mathrm{C} / \mathrm{N}$ ratio. Legume-based cover crops provide greater contribution to soil N (Silva et al., 2006b; Acosta et al., 2011; Carvalho et al., 2011, 2014) and can increase maize crop yield in succession (Amado et al., 2002; Silva et al., 2006b). Grasses increase the permanence of straw on the soil surface by possessing a higher $\mathrm{C} / \mathrm{N}$ ratio, and thus, have lower a decomposition rate (Lara Cabezas et al., 2004). As N is required in large amounts for maize production, it is of great importance to understand the capacity of green manures to supply $\mathrm{N}$ requirements for maize production.

The objectives of this study were to estimate the $\mathrm{N}$ utilization of ${ }^{15} \mathrm{~N}$-urea fertilizer and cover crop residues labelled with ${ }^{15} \mathrm{~N}$ by maize crops grown in succession, and evaluate the effects of the isolated and combined use of cover crops and urea on maize plant height, yield components, and grain yield under a no-tillage system.

\section{Results and discussion}

\section{Cover crops production and characterization}

At 72 days after sowing (DAS), the dry matter yield of cover crops followed the order: millet > sunn hemp > green velvet bean > pigeon pea > spontaneous vegetation (Table 1 ). Previous studies by Bordin et al. (2003) showed lower dry matter yield for sunn hemp (6.85 $\mathrm{Mg} \mathrm{ha}^{-1}$ ) and millet ( 9.60 $\mathrm{Mg} \mathrm{ha}^{-1}$ ) after 70 DAS. However, in two consecutive crops, Cazetta et al. (2008) achieve cutting the plants at 60 DAS; lower dry matter yield for sunn hemp, pigeon pea, and spontaneous vegetation (fallow); higher values for velvet bean, and similar for millet. In general, biomass production and nutrient uptake is an intrinsic characteristic of each cover crop species (Carvalho et al., 2011). However, they are strongly influenced by the soil and climatic conditions of the region, as well as the growing season (Lara Cabezas et al., 2004).

The sunn hemp, green velvet bean, pigeon pea, and spontaneous vegetation had higher $\mathrm{N}$ concentrations in dry matter and lower $\mathrm{C} / \mathrm{N}$ ratios than the millet (Table 1 ). This was expected, as legume crop residues contain high levels of $\mathrm{N}$ compared with non-legume crops because of their ability to fix atmospheric $\mathrm{N}$ through biological nitrogen fixation and absorb it in the plant tissues (Ambrosano et al., 2003; Silva et al., 2008; Carvalho et al., 2015).

The ${ }^{15} \mathrm{~N}$ enrichment of cover crops showed that millet had a higher ${ }^{15} \mathrm{~N}$ enrichment than the legumes (Table 1 ). This is likely to occur, due to the symbiotic association between legumes and the bacteria of the genus Rhizobium, which promotes biological nitrogen fixation (BNF) of atmospheric $\mathrm{N}$, thus diluting the ${ }^{15} \mathrm{~N}$ applied in the fertilizer (Silva et al., 2006b). Millet, being a non-leguminous crop, obtained most of the $\mathrm{N}$ from the applied fertilizer and, as a result, contains higher ${ }^{15} \mathrm{~N}$ in the plant. Studies have shown that $\mathrm{N}$ which is derived from BNF in legume green manures usually contains an average of more than $60 \%$ of accumulated fraction (Muraoka et al., 2002; Scivittaro et al., 2004).

The highest levels of lignin occurred in green velvet bean, which was followed by pigeon pea; the lowest were observed in millet and spontaneous vegetation (Table 1). The highest total phenol contents occurred in spontaneous vegetation, and the lowest was observed in millet (Table 1). The decomposition of crop residues is associated with their chemical and organic composition, especially the contents of cellulose, hemicellulose, lignin, polyphenols, and $\mathrm{N}$, as well as their ratios such as $C / N, C / P$, lignin/ $N$, polyphenols/ $N$, and polyphenols + lignin/ N (Myers et al., 1994; Carvalho et al., 2015). Plant residues containing low concentrations of $\mathrm{N}$ and high lignin and polyphenol contents decompose slowly and, as a result, release nutrients at a slower rate (Boer et 
al., 2007; Silva et al., 2008). The $\mathrm{C} / \mathrm{N}$ ratio alone does not represent the decomposition process of organic materials well, as it does not consider the quality of carbon (Carvalho et al., 2011).

Thus, rotation with leguminous cover crops can result in significant inputs of $\mathrm{N}$ into the soil-plant system and subsequent crops (Silva et al., 2006b; Acosta et al., 2011; Carvalho et al., 2014, 2015). Studies carried out by Perin et al. (2004) showed that sunn hemp stood out in the phytomass yield, being $108 \%$ greater than the spontaneous vegetation and $31 \%$ superior to millet, being that the presence of sunn hemp resulted in larger contents of $\mathrm{N}$ and $\mathrm{Ca}$, while millet and spontaneous vegetation showed a higher $\mathrm{K}$ content. The studies also showed that BNF was $61 \%$ during intercropping with millet and $57 \%$ during sole cropping, and that incorporating the soil via BNF 89 and 173 $\mathrm{kg} \mathrm{ha}^{-1} \mathrm{~N}$, respectively, is an excellent strategy for increasing soil $\mathrm{N}$.

\section{Maize grain yield, straw, and production components as affected by $N$ rates and cover crops}

The plant height and ear height were higher for the maize grown in succession to legume crops than those grown in succession to millet or fallow (Table 2 ). In relation to mineral $\mathrm{N}$ rates, there was a quadratic response for plant height and a linear response for ear height (Figure 1A), with the lowest heights observed for treatments which received no $\mathrm{N}$. This is due to the important requirement for $\mathrm{N}$ in the process of photosynthesis, cell division, and expansion (Marschner, 1995; Malavolta et al., 1997). Regarding the number of rows per ear, grains per row, and the number of grains per ear, the highest values were in the treatments in which maize is grown in succession to legumes or fallow (Table 1 ).

The highest maize weight per thousand grains was obtained in the treatments preceded by legumes; by comparison, there was no significant difference where maize succeeded fallow or millet (Table 2). The number of rows per ear was increased following the increase $\mathrm{N}$ fitting a quadratic model, whereas the number of grains per row (Figure 1B), as well as the number of grains per ear and weight per thousand grains (Figure $1 \mathrm{C}$ ) increased linearly with the $\mathrm{N}$ rate. Also, in soils and climatic conditions similar to the present study, Costa et al. (2012) observed that in maize grown in succession to grasses, the nitrogen fertilizer up to $200 \mathrm{~kg} \mathrm{ha}^{-1} \mathrm{~N}$ provided linear increases in leaf chlorophyll index, the $\mathrm{N}, \mathrm{P}$, and $\mathrm{S}$ contents, production components, and grain yield of maize. There was significant interaction between the $\mathrm{N}$ fertilizer and cover crops for the grain yield of maize (Figure 1D). The highest maize grain yields in treatments without mineral $\mathrm{N}$ were obtained where legume had been grown previously, whereas the lowest yields were observed where millet or fallow soil was previously utilized (Table 2). Except for the fallow treatment that received $150 \mathrm{~kg} \mathrm{ha}^{-1} \mathrm{~N}$, the highest grain yield was obtained where maize preceded a legume cover crop, irrespective of the $\mathrm{N}$ rate. Furthermore, yield did not significantly differ between rates of $\mathrm{N}$ where a legume cover crop was used. The presence of legume residues associated with $30 \mathrm{~kg} \mathrm{ha}^{-1} \mathrm{~N}$ applied at sowing provided a grain yield higher than that with the application of $90 \mathrm{~kg} \mathrm{ha}^{-1}$ $\mathrm{N}$ where millet or fallow was used in the sequence (Figure 1D). Based on the maize yield in the legume treatments without mineral $\mathrm{N}$ application, the response in grain yield would be equivalent to applying $80 \mathrm{~kg} \mathrm{~N} \mathrm{ha}^{-1}$ to maize grown in fallow soil, and $108 \mathrm{~kg} \mathrm{ha}^{-1} \mathrm{~N}$ to maize grown in succession to millet (Figure 1D). Under the no-tillage system in
Southern Brazil, studies conducted by Acosta et al. (2011) observed that the recovery of hairy vetch ${ }^{15} \mathrm{~N}$ by maize was low (12.3\% at harvest). Although hairy vetch was not the main source of maize $\mathrm{N}$ nutrition, the crop yield reached 8.2 $\mathrm{Mg} \mathrm{ha}{ }^{-1}$ without $\mathrm{N}$ mineral fertilization. There was an apparent synergism between hairy vetch residue application and the mineral $\mathrm{N}$ fertilization rate of $60 \mathrm{~kg} \mathrm{ha}^{-1}$, confirming the benefits of the combination of organic and inorganic $\mathrm{N}$ sources for maize under no tillage. Balkcom and Reeves (2005) estimated that the $N$ fertilizer equivalence of sunn hemp residues to a following maize crop averaged $58 \mathrm{~kg} \mathrm{ha}^{-1}$ $\mathrm{N}$. The results of this study are similar to those reported by Silva et al. (2006b), also for Cerrado Oxisol, where the $\mathrm{N}$ recovery from sunn hemp without the application of urea-N was $21.1 \mathrm{~kg} \mathrm{ha}^{-1}$; however, the grain yield $\left(6.41 \mathrm{Mg} \mathrm{ha}^{-1}\right)$ corresponded to the equivalent of the application of $60.5 \mathrm{~kg}$ $\mathrm{ha}^{-1} \mathrm{~N}$ as urea, maize grown after fallow in the off-season, and $89.0 \mathrm{~kg} \mathrm{ha}^{-1} \mathrm{~N}$ for maize in succession to millet. Therefore, growing a legume cover crop in the off-season can increase the amount of $\mathrm{N}$ recovered from legumes for commercial cultivation and help to improve system yield. It is important to note that the difference in yield between the treatments receiving 90 or $150 \mathrm{~kg} \mathrm{ha}^{-1} \mathrm{~N}$ is not economically feasible, considering the shared cost of fertilizer and its application (Figure 1D). Nitrogen is the most required nutrient, is used in larger quantities, and is the one that most influences maize yield. However, it is also the main factor that burdens the cost of production of such crops in Brazil (Cantarella, 2007; Silva et al., 2007). It is concluded that $\mathrm{N}$ fertilizer must be applied to maize crops at sowing, even using as a legume, with $\mathrm{N}$ applied; thus, this slower $\mathrm{N}$ release from the decomposing of cover crop residues may represent increased resource efficiency while reducing losses of $\mathrm{N}$ (Cantarella, 2007). In general, the maximum grain yield response to $\mathrm{N}$ was obtained by applying $30 \mathrm{~kg} \mathrm{ha}{ }^{-1}$, suggesting the importance of implementing the nutrient at sowing. It is noteworthy that although there was a linear response for grain yield with increasing $\mathrm{N}$ rates with the use of legumes, the application of only $30 \mathrm{~kg} \mathrm{ha}^{-1}$ at sowing proportioned grain yield above 7 $\mathrm{Mg} \mathrm{ha}{ }^{-1}$. It may be concluded that $\mathrm{N}$ fertilizer must be applied to maize crop at sowing, even using legume, with $\mathrm{N}$ applied as a topdressing when proceeding millet or fallow ground. Millet resulted in the lowest grain maize yield compared to legumes, regardless of the $\mathrm{N}$ rate. This occurs because of the potential for $\mathrm{N}$ immobilization following high $\mathrm{C} / \mathrm{N}$ ratio cover crops, $\mathrm{N}$ fertilizer rates may need to be increased, particularly where large amounts of residue are produced (Amado et al., 2002; Lara Cabezas et al., 2004; Silva et al., 2006a; Boer et al., 2007; Carvalho et al., 2015). The results from this study suggest that, among other factors, the level of technology and the expected grain yield should be considered in relation to the $\mathrm{N}$ recommendation for maize grown in succession to legume cover crops. With adequate dry matter yield, legumes can provide a grain yield above $6 \mathrm{Mg} \mathrm{ha}^{-1}$ without $\mathrm{N}$ fertilization.

\section{Nitrogen uptake by maize (straw and grain) plant}

The total amount of $\mathrm{N}$ accumulated in maize straw and grain increased by quadratic form in relation to the mineral $\mathrm{N}$ rate applied (Figure 2A). The different cover crops species grown before maize cultivation did not affect the amount of $\mathrm{N}$ derived from fertilizer urea (NPDFF) by maize straw and grain. Likewise, the fraction of $\mathrm{N}$ in the maize crop derived from mineral fertilizer urea (\%NPDFF) and the amount of $\mathrm{N}$ 
Table 1. Dry matter yield, nitrogen $(\mathrm{N})$ content and accumulated ${ }^{15} \mathrm{~N}$ concentration, carbon $(\mathrm{C})$ content, $\mathrm{C} / \mathrm{N}$ ratio, lignin, and total phenols in the shoots of sunn hemp, pigeon pea, green velvet bean, millet, and spontaneous vegetation, grown before maize cultivation in Selvíria, MS, Brazil

\begin{tabular}{|c|c|c|c|c|c|c|c|c|}
\hline Cover crops & $\begin{array}{l}\text { Dry } \\
\text { Matter }\end{array}$ & $\begin{array}{l}\mathrm{N} \\
\text { Content }\end{array}$ & $\begin{array}{l}\mathrm{N} \\
\text { Accumulated }\end{array}$ & $\begin{array}{l}{ }^{15} \mathrm{~N} \\
\text { Plant }\end{array}$ & C & C/N Ratio & Lignin & Phenols ${ }^{(*)}$ \\
\hline & tha $^{-1}$ & $\mathrm{~g} \mathrm{~kg}^{-1}$ & $\mathrm{~kg} \mathrm{ha}^{-1}$ & $\%$ & $\mathrm{~g} \mathrm{~kg}^{-1}$ & & $\mathrm{~g} \mathrm{~kg}^{-1}$ & \\
\hline Sunn hemp & $8.42 b$ & $18.7 b$ & $157.8 \mathrm{a}$ & 1.846 & 405 & $21.7 b$ & $113.8 \mathrm{bc}$ & $18.14 a b$ \\
\hline Pigeon pea & $5.62 \mathrm{c}$ & $20.5 b$ & $115.5 \mathrm{~b}$ & 1.425 & 450 & $22.0 \mathrm{~b}$ & $141.1 \mathrm{ab}$ & $16.51 \mathrm{ab}$ \\
\hline Velvet bean & $5.87 \mathrm{c}$ & $24.7 \mathrm{a}$ & $144.9 \mathrm{a}$ & 1.981 & 414 & $16.8 \mathrm{~b}$ & $180.7 \mathrm{a}$ & $18.48 \mathrm{ab}$ \\
\hline Millet & $13.6 \mathrm{a}$ & $7.80 \mathrm{c}$ & $106.8 \mathrm{~b}$ & 2.251 & 421 & $54.0 \mathrm{a}$ & $68.20 \mathrm{c}$ & $13.61 \mathrm{~b}$ \\
\hline S. vegetation & $2.95 \mathrm{~d}$ & $14.2 \mathrm{~b}$ & $42.00 \mathrm{c}$ & - & 424 & $29.9 b$ & $93.70 \mathrm{bc}$ & $20.50 \mathrm{a}$ \\
\hline
\end{tabular}

Values followed by the same letters in columns are not significantly different $(\mathrm{p}<0.05)$ amongst themselves (by Tukey test). ${ }^{*}$ Values are expressed in equivalent grams of tannic acid / kg of dry matter.

Dlant height $\hat{y}=2.15+0.003 \mathrm{~N}-0,000014 \mathrm{~N}^{2} \mathrm{R}^{2}=0.928 * *$

$\Delta$ Ear height $\hat{\mathrm{y}}=1.18+0.0008 \mathrm{~N} \mathrm{R}^{2}=0.808^{* *}$

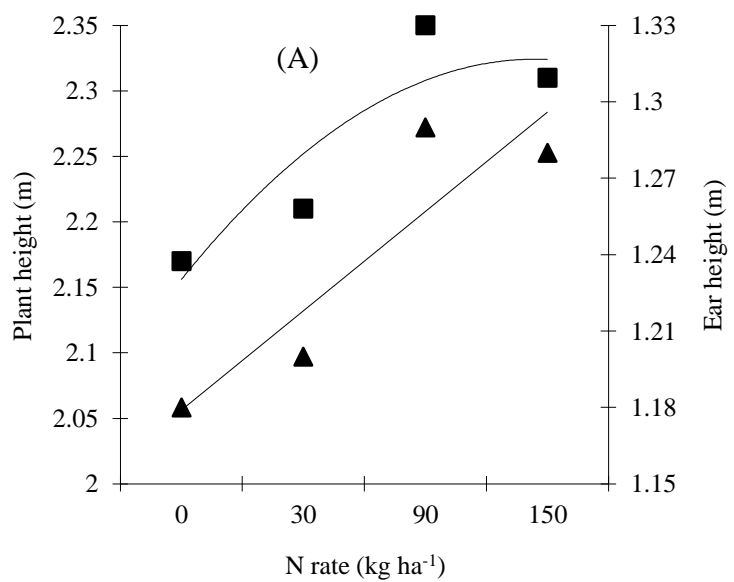

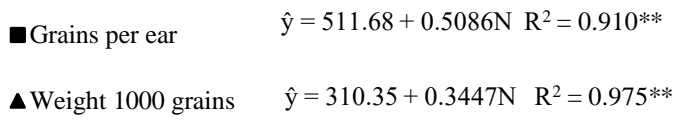

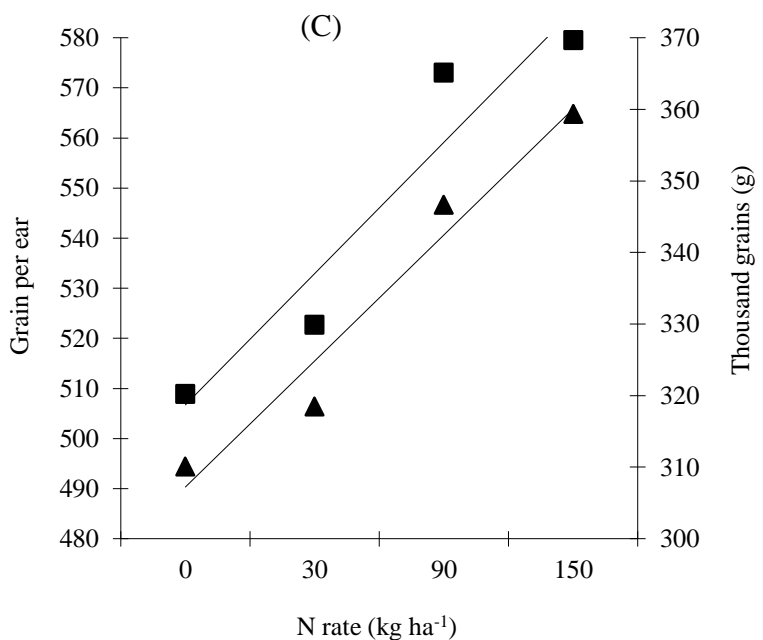

Rows per ear $\hat{\mathrm{y}}=14.2+0.019 \mathrm{~N}-0.0001 \mathrm{~N}^{2} \mathrm{R}^{2}=0.915^{* *}$

$\Delta$ Grains per row $\hat{\mathrm{y}}=35.6+0.0287 \mathrm{~N} \quad \mathrm{R}^{2}=0.879 * *$

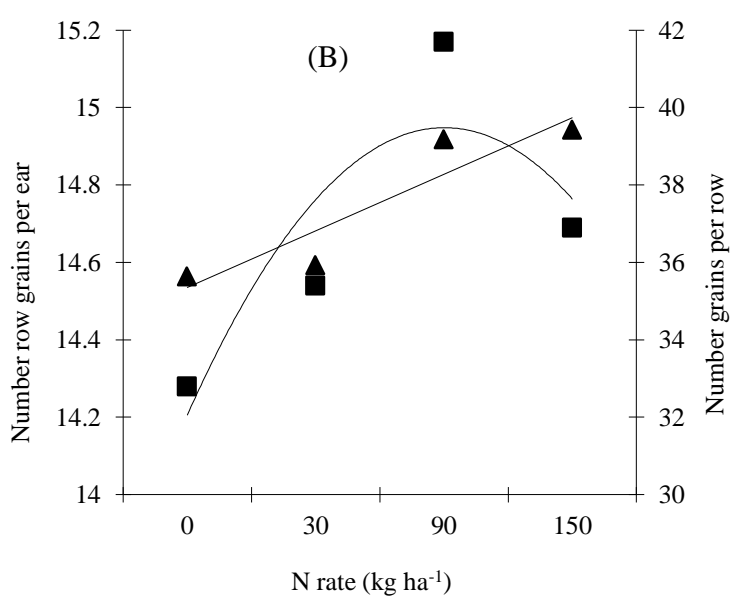

- Sunnhemp $=6,470.69+10.655 \mathrm{~N} \mathrm{R}^{2}=0.844 * *$

口Pigeon pea $=6,440.45+14.062 \mathrm{~N} \mathrm{R}^{2}=0.945^{* *}$

$\Delta$ Velvet bean $=6,450.38+12.304 \mathrm{~N} \mathrm{R}^{2}=0.828 * *$

$\bullet$ Fallow $\quad=4,092.35+25.533 \mathrm{~N} \mathrm{R}^{2}=0.997 * *$

口Millet $\quad=3,392.60+25.463 \mathrm{~N} \mathrm{R}^{2}=0.994 * *$

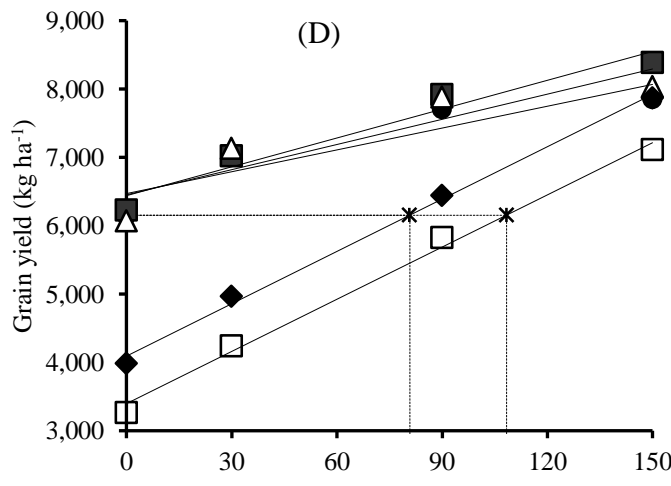

$\mathrm{N}$ rate $\left(\mathrm{kg} \mathrm{ha}^{-1}\right)$

Fig 1. Plant and first-ear height (A), grain per row and row per ear (B), grains per ear and thousand grain weight (C), and grain yield (D), as affected by nitrogen rates and cover crops in Selvíria, MS, Brazil. ** Significant by the $\mathrm{F}$ test at $1 \%$. 
Table 2. Plant height, ear height, grain per rows, rows of grain per ear, grains per ear, and thousand grain weight as affected by cover crops and nitrogen rates in Selvíria, MS, Brazil

\begin{tabular}{lcccccc}
\hline Species & Plant height & Ear height & Grain per row & Row per ear & Grain per ear & Weight 1000 grains \\
\cline { 2 - 7 } Sunn hemp & $2.32 \mathrm{ab}$ & $1.29 \mathrm{a}$ & $38.72 \mathrm{a}$ & $14.50 \mathrm{~b}$ & $558.25 \mathrm{a}$ & $\mathrm{g}$ \\
Pigeon pea & $2.28 \mathrm{~b}$ & $1.27 \mathrm{a}$ & $37.68 \mathrm{ab}$ & $14.92 \mathrm{a}$ & $554.99 \mathrm{a}$ & $346.45 \mathrm{a}$ \\
Bean velvet & $2.35 \mathrm{a}$ & $1.30 \mathrm{a}$ & $37.81 \mathrm{ab}$ & $14.96 \mathrm{a}$ & $562.50 \mathrm{a}$ & $347.77 \mathrm{a}$ \\
Millet & $2.20 \mathrm{c}$ & $1.19 \mathrm{~b}$ & $37.54 \mathrm{ab}$ & $14.33 \mathrm{~b}$ & $509.70 \mathrm{~b}$ & $305.40 \mathrm{~b}$ \\
Fallow & $2.17 \mathrm{c}$ & $1.13 \mathrm{c}$ & $35.99 \mathrm{~b}$ & $14.62 \mathrm{ab}$ & $544.54 \mathrm{a}$ & $322.52 \mathrm{~b}$ \\
\hline
\end{tabular}

Values followed by the same letters in columns do not differ $(p<0.05)$ amongst themselves (by the Tukey's test).
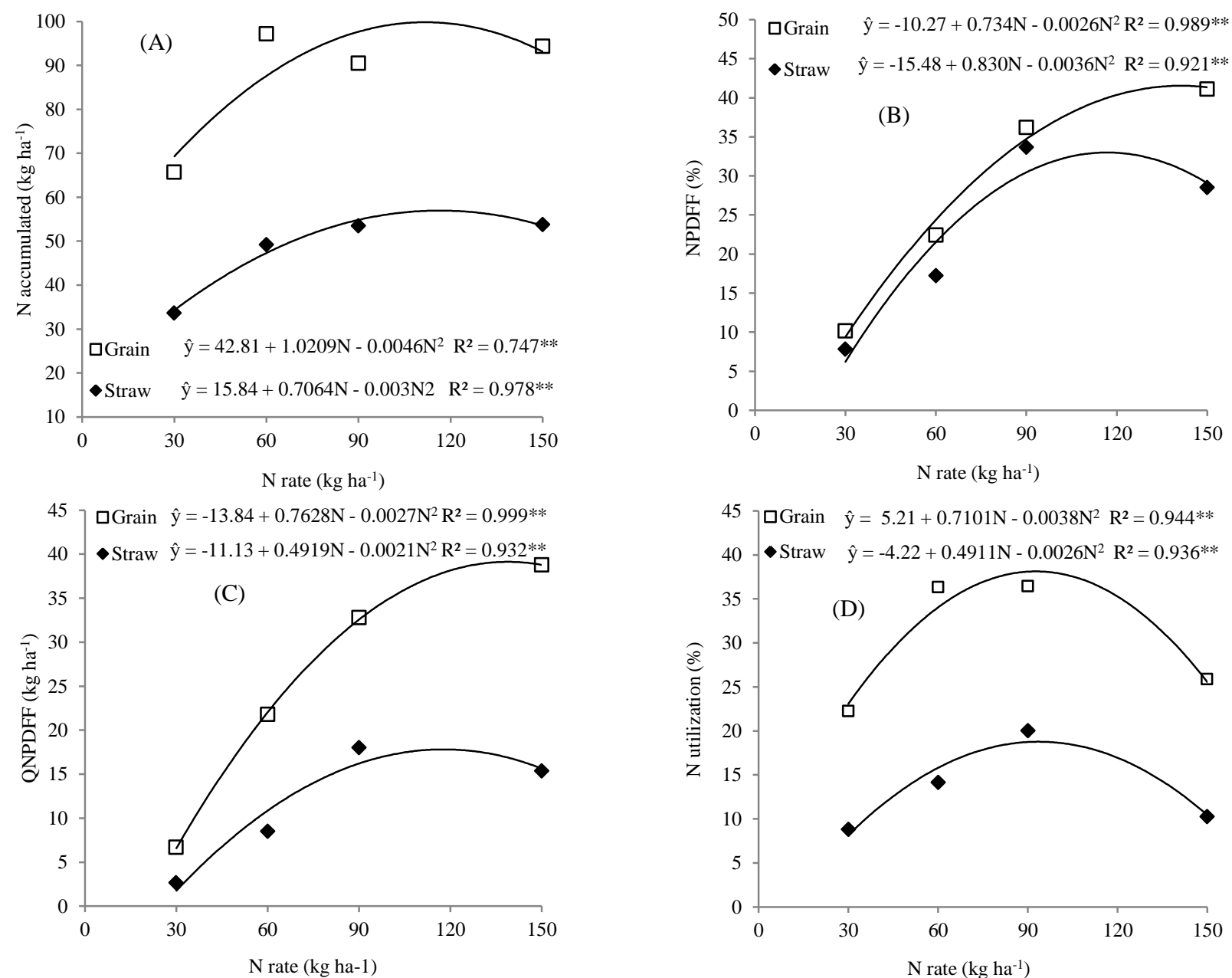

Fig 2. Nitrogen accumulated in the straw and grain maize (A), percentage (B), amount of nitrogen derived from fertilizer urea (NPDFF) in the straw and grain maize (C), and \% nitrogen utilization from cover crops (D), as affected by nitrogen rates in Selvíria, MS, Brazil. ** Significant by the $\mathrm{F}$ test at $1 \%$.
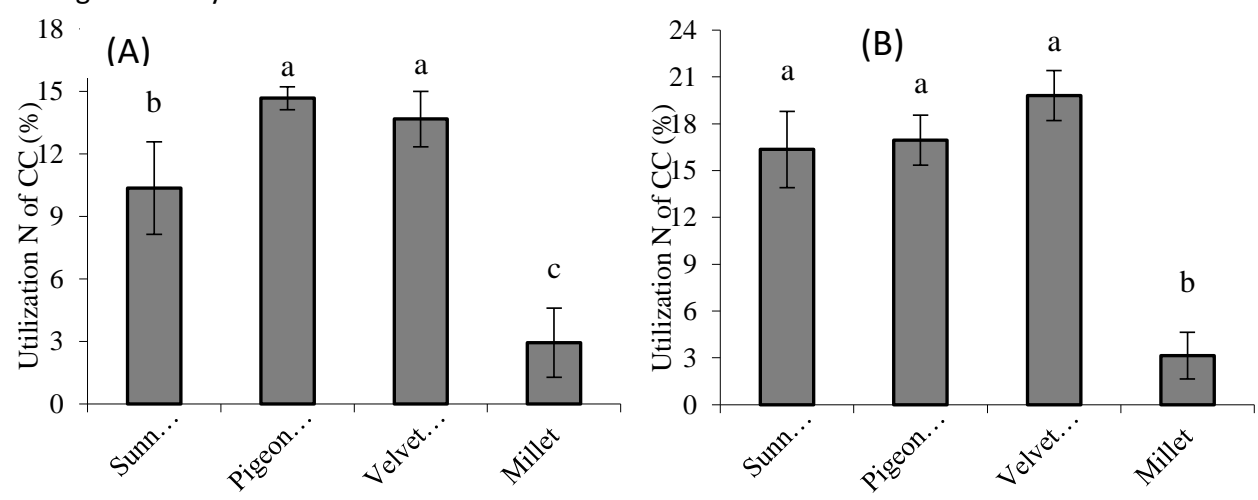

Fig 3. Nitrogen derived from cover crops (NPDFCC) (A) in maize (straw + grain) and utilization of nitrogen derived from cover crops by maize plants (B) in Selvíria, MS, Brazil. Bars denoted by the same letter did not differ significantly $(p<0.05)$ according to Tukey's. 
in the plant derived from the fertilizer (NPDFF kg ha ${ }^{-1}$ ) also adjusted to a quadratic regression model (Figure $2 \mathrm{~B}$ and $2 \mathrm{C}$ ). In another study conducted in the same region, previously grown sunn hemp resulted in a higher shoot dry matter and total $\mathrm{N}$ accumulated by maize (Kappes et al., 2013).

The $\mathrm{N}$ derived from mineral fertilizer in maize straw and grain increased with increasing $\mathrm{N}$ rates up to $94 \mathrm{~kg} \mathrm{ha}^{-1} \mathrm{~N}$. From this point it decreased in quadratic form with increasing $\mathrm{N}$ rates (Figure 2D), which is consistent with previous results (Muraoka et al., 2002; Silva et al. 2006a, 2009). However, it is emphasized that the $\mathrm{N}$ recovery is a relative value to the applied $\mathrm{N}$ rate and, as observed in this study (Figure 2C), the amount of NPDFF in maize plant generally increases with increasing applied $\mathrm{N}$ rate (Silva et al., 2006a; Duete et al., 2008). Regarding the urea $\mathrm{N}$ utilization, similar result to this study, for maize grown on velvet bean residues, were also observed by Scivittaro et al. (2000).

On average, the urea $\mathrm{N}$ utilization by maize straw and grain was $43.5 \%$ of the applied $\mathrm{N}$ (Figure 2D). Different $\mathrm{N}$ utilization values (39-57\%) have been reported for studies with maize in Oxisol using ${ }^{15} \mathrm{~N}$ labelled techniques (Grove et al., 1980; Coelho et al., 1991; Villas Bôas et al., 1999; Scivittaro et al., 2000; Figueiredo et al., 2005; Silva et al, 2006a; Gava et al., 2006; Duete et al., 2008). This variation in the $\mathrm{N}$ utilization from mineral fertilizers by maize is due to several factors, mainly the soil and climate conditions, the type of $\mathrm{N}$ fertilizer used, the fertilizer application methods (rate, time application), and cropping systems (no-tillage or conventional tillage) (Lara Cabezas et al., 2004; Duete et al., 2008). Also, $N$ losses by leaching, volatilization, denitrification, erosion, and microbial immobilization will influence the availability of mineral $\mathrm{N}$ in the soil and its utilization by the crop (Amado et al., 2002; Lara Cabezas et al., 2004; Cantarella, 2007).

The $\mathrm{N}$ utilization by maize plants applied at sowing was lower than when applied at sowing in addition to topdressing (Figure 2D). This may be due to the lower demand of the $\mathrm{N}$ by the crop at an early stage (Varvel et al., 1996; Silva et al., 2006a) leading to increased susceptibility to losses and microbial immobilization.

Based on the total partition $\mathrm{N}$ accumulated in the maize crop (Figure 2A), as well as $\mathrm{N}$ from fertilizer in straw and grain (Figure 2C), it appears that an average of two-thirds is allocated to grains and the remainder to straw, including crop residues that remain in the soil after the harvest of maize. Similar results were also observed by Coelho et al. (1991) and Silva et al. (2006a, b).

\section{Cover crop $\mathbf{N}$ utilization by maize}

The contribution of cover crops to maize $\mathrm{N}$ in relation to that derived from fertilizer (NPDFCC) did not differ significantly among the legume cover crops (Figure 3A). However, when $\mathrm{N}$ recovery is considered, which is relative to the amount of $\mathrm{N}$ applied as residues, there were differences even among the legume cover crops, that is, green velvet bean (13.7\%) and pigeon pea (14.7\%) performed better than sunn hemp $(10.4 \%)$. The millet (3.0\%) was significantly lower than the three legumes (Figure 3B). The results of this study are similar to those obtained by Acosta et al. (2011), in which the hairy vetch $\mathrm{N}$ utilization by maize was an average of 12.3 $\%$, and by Scivittaro et al. (2003), in which the velvet bean $\mathrm{N}$ utilization by maize averaged $10-14 \%$. Silva et al. (2006b) have already shown maize $\mathrm{N}$ utilization ranging from 3.4$11.9 \%$ and $12.0-21.9 \%$ for millet and sunn hemp, respectively, by maize grown under no-tillage.

The results from the study showed that legume cover crop residues (sunn hemp, green velvet bean, and pigeon pea) provided more $\mathrm{N}$ to maize grown in sequence, compared to millet residues (Figures $3 \mathrm{~A}$ and $3 \mathrm{~B}$ ). This is in spite of larger amounts of $\mathrm{N}$ in the millet residues, which suggests that residues of these three cover crops favored soil conditions for $\mathrm{N}$ uptake by the maize and, consequently, growth and plant development. This may be due to its low $\mathrm{C} / \mathrm{N}$ ratio that has conditions for the faster and more regular release of $\mathrm{N}$ and other nutrients that are mineralized concomitantly to $\mathrm{N}$. Millet on the other hand, due to its high $\mathrm{C} / \mathrm{N}$ ratio, causes the temporary immobilization of $\mathrm{N}$ leading to a lower contribution of $\mathrm{N}$ to maize. Leal et al. (2013) also observed that sunn hemp was more efficient than millet as a cover crop to supply $\mathrm{N}$ for subsequent maize crops. Studies have shown that the phase (phenological stage) during which $\mathrm{N}$ is directly absorbed by the maize plant influences the accumulation of dry matter for maize (Varvel et al., 1997, Silva et al., 2006a; Cantarella, 2007).

On average, more than $85 \%$ of the $\mathrm{N}$ from the cover crop residues was not utilized by maize grown in succession. In this respect, most studies demonstrated that the majority of $\mathrm{N}$ from cover crop residues accumulates in the soil, predominantly in organic form (Harris et al., 1994; Silva et al., 2006b; Acosta et al., 2011; Carvalho et al., 2014). Studies have reported that less than $50 \%$ of the $\mathrm{N}$ incorporated into soil in its organic form is transformed into inorganic $\mathrm{N}$ by mineralization and that the other portion is found in association with the soil microbial biomass (Mengel, 1996). This highlights the need to emphasize soil management systems for crops (rotation/succession) and $\mathrm{N}$ fertilizer that contribute adequate amounts of $\mathrm{N}$ to maize crops, whether in its organic or in inorganic form, to maintain the long term productivity of soils.

The results indicated that there may be an opportunity to reduce $\mathrm{N}$ fertilizer inputs while increasing maize yields by growing maize in succession with legume cover crops. These findings are in agreement with those of other researchers, who reported that summer leguminous cover crops, such as pigeon pea, sunn hemp, and cowpea, have the potential to reduce and/or supplement the fertilizer $\mathrm{N}$ requirement for maize crops (Mahama et al., 2016). These are important considerations in Brazil where resources are limited and there is a need to improve agricultural yield and environmental sustainability simultaneously.

Materials and methods

\section{Location, soil conditions, and climate}

The field study was carried out at the Experimental Farm of Faculty of Engineering, Sao Paulo State University, located in Selvíria-MS, Brazil (51 22' W and 20 22' S, 335 m of altitude). The soil is classified as Dystropherric Typic Rhodic Haplustox soil (Soil Survey Staff, 2010) and Latossolo Vermelho Distroférrico, Loamy, |Cerrado (Savanah) phase (Santos et al., 2013). The experimental area has a history of 19 years under conventional tillage and the last 12 years in no-tillage.

The initial chemical characteristics of the soil, analyzed according to methods described by Raij et al. (2001) for the layers of $0-0.10$ and $0.10-0.20 \mathrm{~m}$ were, respectively: $\mathrm{pH}$ $\left(\mathrm{CaCl}_{2}\right) 4.9$ and 4.7 ; total $\mathrm{N} 1.0$ and $0.8 \mathrm{~g} \mathrm{~kg}^{-1}$; organic matter 26.0 and $22.0 \mathrm{~g} \mathrm{dm}^{-3} ; \mathrm{P}$ (resin extractable) 30 and $25 \mathrm{mg} \mathrm{dm}^{-}$ ${ }^{3} ; \mathrm{Ca}^{2+} 32$ and $20 \mathrm{mmol}_{\mathrm{c}} \mathrm{dm}^{-3} ; \mathrm{Mg}^{2+} 18$ and $12 \mathrm{mmol}_{\mathrm{c}} \mathrm{dm}^{-3} ; \mathrm{K}^{+}$ 
2.0 and $2.6 \mathrm{mmol}_{\mathrm{c}} \mathrm{dm}^{-3} ; \mathrm{S} 4.0$ and $3.5 \mathrm{mg} \mathrm{dm}^{-3} ; \mathrm{H}+\mathrm{Al} 31$ and $38 \mathrm{mmol}_{\mathrm{c}} \mathrm{dm}^{-3}$; CEC 83.0 and $72.6 \mathrm{mmol}_{\mathrm{c} \mathrm{dm}} \mathrm{dm}^{-3}$; base saturation 62.7 and $47.7 \%$.

\section{Labeling the coverage plants with ${ }^{15} \mathrm{~N}$}

The field experiment comprised two phases: initially (winter/spring season) in the first phase, cover crops were sown $0.40 \mathrm{~m}$ between rows for legume species (sunn hemp, pigeon pea, and velvet bean) and $0.25 \mathrm{~m}$ for millet, and an area was left with spontaneous vegetation during the fallow ground off-season. In the second phase (spring/summer season), maize crops were grown on soil with cover crop residues under a no-tillage system.

${ }^{15} \mathrm{~N}$ labeled sunn hemp, pigeon pea, velvet bean, and millet plants were obtained by growing them simultaneously in an area adjacent to the main experiment, and applying an equivalent of $40 \mathrm{~kg} \mathrm{~N}$ ha ${ }^{-1} \mathrm{~N}$ as urea- ${ }^{15} \mathrm{~N}$ (labelled with $10.37 \%$ atom ${ }^{15} \mathrm{~N}$ ) in three equal splits at 20,34 , and 48 days after emergence ( $1^{\text {st }}$ application to the soil; $2^{\text {nd }}$ application $1 / 2$ to the soil and $1 / 2$ foliar application, and $3^{\text {rd }}$ application for foliar spraying only). The ${ }^{15} \mathrm{~N}$ labeled plants were harvested at the same time as the unlabeled plants. Samples were taken for chemical and isotopic ${ }^{15} \mathrm{~N}$ analysis. The spontaneous vegetation plants were not labelled with ${ }^{15} \mathrm{~N}$. The objective of this step was to label the cover plants with ${ }^{15} \mathrm{~N}$ present in the urea, in order to track the $\mathrm{N}$ that these cover crops would provide for maize in the next crop cycle. The ${ }^{15} \mathrm{~N}$ labeled plants were manually collected and cut into small pieces, as were the unlabeled plants. The cover crops and spontaneous vegetation were cut mechanically by a crusher with straw and herbicide glyphosate up until 72 days after sowing (DAS). Crop residues were left on the soil surface and used as mulch in the field. In the cover crops microplots, unlabeled sunn hemp, pigeon pea, velvet bean, and millet plant material were substituted by equivalent amounts of ${ }^{15} \mathrm{~N}$ labeled plants $(1.846,1.425,1.981$, and $2.251 \%$ atom ${ }^{15} \mathrm{~N}$, for sunn hemp, pigeon pea, velvet bean, and millet, respectively).

\section{Experimental design and characterization of treatments}

In the maize crop (second phase), the experimental design was randomized blocks with 20 treatments and four replications in a $5 \times 4$ factorial arrangement. The treatments were five cover crop species, sunn hemp (Crotalaria juncea L.), pigeon pea (Cajanus cajan L.), green velvet bean (Mucuna prurens), millet (Pennisetum glaucum L.), and spontaneous vegetation (fallow), combined with four $\mathrm{N}$ rates $\left(0,30,90\right.$, and $\left.150 \mathrm{~kg} \mathrm{ha}{ }^{-1}\right)$, using the urea- ${ }^{15} \mathrm{~N}$ fertilizer, which was only applied to maize grown in succession. In order to achieve a minimum of four points in the regression curve in the $\mathrm{N}$-recovery as a function of the doses, it was necessary to insert one more dose $\left(60 \mathrm{~kg} \mathrm{ha}^{-1}\right)$, because in these analyses the dose 0 is excluded since there is no nitrogen and it is impossible to trace. This limitation generated data with the following nitrogen rate ranges: 0 , 30,90 , and $150 \mathrm{~kg} \mathrm{ha}^{-1}$ and others with $30,60,90$, and 150 $\mathrm{kg} \mathrm{ha}{ }^{-1}$. The urea- ${ }^{15} \mathrm{~N}$ and ${ }^{15} \mathrm{~N}$-labelled cover crop residues were added on different microplots, to distinguish $\mathrm{N}$ derived from respective sources of this nutrient.

\section{Sowing and fertilization of plots}

The maize (Pioneer hybrid simple 30F80) was mechanically sown with spacing of $0.90 \mathrm{~m}$ between rows and at a density of 5.7 seeds per $m$ of row. Basal fertilization at sowing was $90 \mathrm{~kg} \mathrm{ha}^{-1}$ of $\mathrm{P}_{2} \mathrm{O}_{5}$ and $60 \mathrm{~kg} \mathrm{ha}^{-1} \mathrm{~K}_{2} \mathrm{O}$, as single superphosphate and potassium chloride. Except for the control (without mineral $\mathrm{N}$ ), $\mathrm{N}$ was applied manually at $30 \mathrm{~kg}$ $\mathrm{ha}^{-1} \mathrm{~N}$, at seeding and with the remainder as topdressing, between rows at the four-leaf stage.

The experimental plots had a width of $7.2 \mathrm{~m}$ and a length of $10.0 \mathrm{~m}$ and treatments that received a ${ }^{15} \mathrm{~N}$-labeled source (plant residues or urea) had their own (separated) microplots of $1.0 \times 2.70 \mathrm{~m}$. As a useful area of the plots, it was considered as the central part, neglecting two rows of maize on each side and 1 meter at the ends. For the microplots, the maize center row was considered as a useful area, with $0.20 \mathrm{~m}$ at the ends being neglected. Supplemental sprinkler irrigation for both cover crops and maize were utilized during the prolonged dry season periods.

\section{Variables analysed}

The plant height and first-ear insertion of maize were measured before harvest. The number of rows per ear, grain per row, and grain per ear were evaluated 20 ears from each plot. Grain yield was determined after manually harvesting five rows of $4 \mathrm{~m}$ of each plot, and determining both the thousand grain weight and grain yield in $\mathrm{kg} \mathrm{ha}^{-1}$.

The $\mathrm{C}$ and $\mathrm{N}$ content of cover crops residues were determined by the dry combustion method $\left(1,400{ }^{\circ} \mathrm{C}\right)$, using the LECO C/N (Nelson and Sommers, 1982). The determinations of total $\mathrm{N}$ and atoms $\%{ }^{15} \mathrm{~N}$ abundance in vegetable material (cover crops, grains, and straw maize) were performed on a mass spectrometer (Isotope Ratio Mass Spectrometry, IRMS) coupled to an automatic analyzer 20-20 ANCA-SL, Europe Scientific, Crewe, according to methodology described by Barrie and Prosser (1996).

The calculations of the total $\mathrm{N}$ accumulated, percentage (NPDFCC), quantity (QNPDFCC) of $\mathrm{N}$ in the maize plants derived from the cover crop, $\mathrm{N}$ derived from urea (NPDFF and QNPDFF), and the $\mathrm{N}$ utilization from cover crops and urea by maize plants were performed according to IAEA (2001). The contribution of $N$ from cover crops in equivalence to $\mathrm{N}$ fertilizer (urea) was obtained by the first derivative of the quadratic polynomial function: $y=c+b N$ $A N^{2}$, equaling it to yield without the $N$ application of the cover crop that provided the highest grain yield of maize.

\section{Statistical analyses}

The obtained data were subjected to analysis of the normal distribution (Shapiro-Wilk) and homoscedasticity of variance (Levene). After meeting the assumptions of the tests, they were then submitted to an analysis of variance (Test F). When significant effects were detected at $5 \%$ probability, a Tukey test at the 0.05 probability was used as a comparison of means. The factors were adjusted to regression equations of $\mathrm{N}$ rates. Lineal and quadratic components were tested, and the model with the most significant degree was chosen. Statistical analyses were carried out using the SAS package, version 8.2 (SAS Institute, Cary, NC, USA).

\section{Conclusion}

Legume cover crops provided maize grain yield equivalent to the application of 80 to $108 \mathrm{~kg} \mathrm{ha}^{-1} \mathrm{~N}$ as urea. The number of grains per spike and the mass of grain were the components that most influenced the maize yield. Legume cover crops, such as sunn hemp, pigeon pea, and green velvet bean, 
provided satisfactory yields of dry matter, and substitution of the $\mathrm{N}$ fertilization can provide an expected yield of $6 \mathrm{Mg}$ $\mathrm{ha}^{-1}$ of grain. The millet cover crop provided a lower maize grain yield compared to legume cover crops, regardless of mineral $\mathrm{N}$ rate applied. The $\mathrm{N}$ recovery of legume cover crops (12.9\%) by maize crop was, on average, four times the $\mathrm{N}$ of millet (3.0\%). Maize crops recovered an average of $43.5 \%$ of applied urea $\mathrm{N}$. The study showed that the introduction of legume cover crops under cropping rotation provides important opportunities to increase both maize grain yield and nutrient utilization.

\section{Acknowledgments}

To Fundação de Amparo à Pesquisa do Estado de São Paulo (Fapesp, Process №. 2008/54502-9), for the research scholarship granted to the first author and for financial support; to International Atomic Energy Agency (IAEA, Project №. RLA 5052), for financial support; to Instituto Federal Goiano - Campus Rio Verde (IF Goiano) for financial support; to Fundação de Amparo à Pesquisa do Estado de Goiás (FAPEG), for the research scholarship granted to the third author; and to Conselho Nacional de Desenvolvimento Científico e Tecnológico (CNPq), for the research fellowship to the others authors.

\section{References}

Acosta JAA, Amado TJC, Neergaard A, Vinther M, Silva LS, Nicoloso RS (2011) Effect of ${ }^{15} \mathrm{~N}$-labeled hairy vetch and nitrogen fertilization on maize nutrition and yield under no-tillage. Rev Bras Cienc Solo. 35:1337-45.

Amado TJC, Milniczuk J, Aita C (2002) Recomendação de adubação nitrogenada para o milho no RS e SC adaptada ao uso de culturas de cobertura do solo, sob sistema plantio direto. Rev Bras Cienc Solo. 26:241-8.

Ambrosano EJ, Trivelin PCO, Cantarella H, Rossetto R, Muraoka T, Bendassolli JA, Ambrosano GMB, Tamiso LG, Vieira FC, Prada Neto I (2003) Nitrogen-15 labeling of Crotalaria juncea green manure. Sci Agric. 60:181-4.

Associação Nacional dos Exportadores de Cereais - ANEC. Área, estatísticas. 2013. Available at: http://www.anec.com.br/estatisticas.html. Accessed December 15, 2018.

Balkcom KS, Reeves DW (2005) Sunn-hemp utilized as a legume cover crop for corn production. Agron J.97:26-31.

Barrie A, Prosser SJ (1996) Automated analysis of lightelement stable isotopes by isotope ratio mass spectrometry. In: Boutton, TW, Yamasaki S, editors. Mass Spectrometry of Soils. New York: Marcel Dekker. p.1-46.

Boer CA, Assis RL, Silva GP, Braz AJBP, Barroso ALL, Cargnelutti Filho A, Pires FR (2007) Ciclagem de nutrientes por plantas de cobertura na entressafra em um solo de cerrado. Pesq Agropec Bras. 42:1269-76.

Bordin L, Farinelli R, Penariol FG, Fornasieri Filho D (2003) Sucessão de cultivo de feijão-arroz com doses de adubação nitrogenada após adubação verde, em semeadura direta. Bragantia.62:417-28.

Cantarella H. Nitrogênio (2007) In: Novais RF, Alvarez VVH, Barros NF, Fontes RLF, Cantarutti RB, Neves JCL, editors. Fertilidade do solo. Viçosa, MG: Sociedade Brasileira de Ciência do Solo. p.375-470.

Carvalho AM, Coser TR, Rein TA, Dantas RA, Silva RR, Souza KW (2015) Manejo de plantas de cobertura na floração e na maturação fisiológica e seu efeito na produtividade do milho. Pesq Agropec Bras. 50:551-61.
Carvalho AM, Marchão RL, Souza KW, Bustamante MMC (2014) Soil fertility status, carbon and nitrogen stocks under cover crops and tillage regimes. $\mathrm{R}$ Cienc Agron.45:914-21.

Carvalho AM, Souza LLP, Guimarães Júnior R, Alves PCAC, Vivaldi J L (2011) Cover plants with potential use for crop livestock integrated systems in the Cerrado region. Pesq Agropec Bras. 46:1200-5.

Cazetta DA, Arf O, Buzetti S, Sà, ME, Rodrigues RAF (2008) Desempenho do arroz de terras altas com a aplicação de doses de nitrogênio e em sucessão às culturas de cobertura do solo em sistema de plantio direto. Bragantia. 67:471-9.

Coelho AM, França GE, Bahia Filho AEC, Guedes GAA (1991) Balanço de nitrogênio $15 \mathrm{~N}$ em um Latossolo VermelhoEscuro, sob vegetação de cerrado, cultivado com milho. Rev Bras Cienc Solo. 15:187-93.

Companhia Nacional de Abastecimento - CONAB (CONAB) Acompanhamento da Safra Brasileira de Grãos 2014/2015. Décimo Segundo Levantamento - Setembro/ 2015. available at: http://www.conab.gov.br/OlalaCMS/uploads/arquivos/15 _09_11_10_42_03_boletim_graos_setembro_2015.pdf. Accessed January 11, 2016.

Costa NR, Andreotti M, Gameiro RA, Pariz CM, Buzetti S, Lopes KSM (2012) Adubação nitrogenada no consórcio de milho com duas espécies de braquiária em sistema plantio direto. Pesq Agropec Bras. 47:1038-47.

Duete RRC, Muraoka T, Silva EC, Trivelin PCO, Ambrosano EJ (2008) Manejo da adubação nitrogenada e utilização do nitrogênio (15N) pelo milho em Latossolo Vermelho. Rev Bras Cienc Solo. 32:161-71.

Empresa Brasileira de Pesquisa Agropecuária - Embrapa (2006) Cultivo do milho. Sete Lagoas: Embrapa Milho e Sorgo. Available at: http://sistemasdeproducao.cnptia.embrapa.br/. Accessed March 25, 2016.

Federação Brasileira de Plantio Direto na Palha - Febrapdp (2012) Evolução da área cultivada em sistema plantio direto na palha no Brasil. Ponta Grossa: 2012. available at: http://www.febrapdp.org.br/download/. Accessed Jan 24, 2018.

Figueiredo CC, Resck DVS, Gomes AC, Urquiaga S (2005) Sistemas de manejo na absorção de nitrogênio pelo milho em um Latossolo Vermelho no Cerrado. Pesq Agropec Bras. 40:279-87.

Gava GJC, Trivelin PCO, Oliveira MW, Heinrichs R, Silva MA (2006) Balanço do nitrogênio da uréia (15N) no sistema solo-planta na implantação da semeadura direta na cultura do milho. Bragantia. 65:477-86.

Grove LT, Richet KD, Maderman GC (1980) Nitrogen fertilization of maize on oxisol of the cerrado of Brazil. Agron J. 27:261-5.

Harris GH, Hesterman OB, Paul EA, Peters SE, Janke RR. (1994) Fate of legume and fertilizer nitrogen-15 in a long term cropping systems experiment. Agron J. 86:910-5.

International Atomic Energy Agency - IAEA (2001) Use of isotope and radiation methods in soil and water management and crop nutrition. Vienna: IAEA. (Training course series, 14).

Kappes C, Arf O, Andrade JAC (2013) Coberturas vegetais, manejo do solo, doses de nitrogênio e seus efeitos na nutrição mineral e nos atributos agronômicos do milho. Rev Bras Cienc Solo. 37:1322-33.

Lara Cabezas WRL, Alves BJR, Urquiaga S, Santana DG (2004) Influência da cultura antecessora e da adubação 
nitrogenada na produtividade de milho em sistema plantio direto e solo preparado. Ci Rural. 34:1005-13.

Leal AJF, Lazarini E, Rodrigues LR, Marcandalli LH (2013) Adubação nitrogenada para milho com o uso de plantas de cobertura e modos de aplicação de calcário. Rev Bras Cienc Solo. 37:491-501.

Machado PLOA, Silva CA (2001) Soil management under notillage systems in the tropics with special reference to Brazil. Nutr Cycl Agroecosyst. 61:119-30.

Mahama GY, Prasad PVV, Roozeboom KL, Nippert JB (2016) Response of maize to cover crops, fertilizer nitrogen rates, and economic return. Agron J. 108:17-31.

Malavolta E, Vitti GC, Oliveira SA (1997) Avaliação do estado nutricional das plantas: princípios e aplicações. 2. ed. Piracicaba: Potafos. 319p.

Maltas A, Corbeels M, Scopel E, Wery J, Macena SFA (2009) Cover crop and nitrogen effects on maize productivity in no-tillage systems of the Brazilian Cerrados. Agron J. 101:1036-46.

Marschner H (1995) Mineral nutrition of higher plants. 2.ed. San Diego: Academic Press.

Mengel, K (1996) Turnover of nitrogen in soil and its availability to crops. Plant Soil. 181:83-93.

Muraoka T, Ambrosano EJ, Zapata F, Bortoletto N, Martins ALM, Trivelin PCO, Boaretto AE, Scivittaro WB (2002) Eficiencia de abonos verdes (crotalaria y mucuna) y urea, aplicadas solos o juntamente, como fuentes de $\mathrm{N}$ para el cultivo de arroz. Terra. 20:17-23.

Myers RJK, Palm CA, Cuevas E, Gunatilleke IUN, Brossard M (1994) The synchronization of nutrient mineralization and, plant nutrient demand. In: Woomer PL, Swift MJ, organizers. The biological management of tropical soil fertility. New York: Wiley-Sayce. p.81-112.

Nelson DW, Sommers LE (1982) Total carbon, organic carbon and organic matter. In: Page AL, Miller RH, Keeney DR, editors. Methods of soil analysis: Chemical and microbiological properties. Part 2. Madison: Soil Sci. Soc. Am. p.539-79.

Ngwira A, Sleutel S, Neve S (2012) Soil carbon dynamics as influenced by tillage and crop residue management in loamy sand and sandy loam soils under smallholder farmers' conditions in Malawi. Nutr Cycl Agroecosyst. 92:315-28.

Perin A, Santos RHS, Urquiaga S, Guerra JGM, Cecon PR (2004) Produção de fitommassa, acúmulo de nutrientes e fixação biológica de nitrogênio por adubos verdes em cultivo isolado e consorciado. Pesq Agropec Bras 39:35-40.

Raij B van, Andrade JC, Cantarella H, Quaggio JÁ (2001) Análise química para avaliação da fertilidade de solos tropicais. Campinas: Instituto Agronômico.

Ranum P, Peña-Rosas JP, Garcia-Casal MN (2014) Global maize production, utilization, and consumption. Ann NY Acad Sci.1312:105-12.

Rosa HA, Secco D, Veloso G, Santos RF, Souza SNM, Marins AC, Borsoi A (2012) Effects of the use of cover crops in the structure of an oxisol managed by a no-till farming system in the west of Paraná, Brazil. J Food Agric Environ. 0:127880.
Rosolem CA, Calonego JC (2013) Phosphorus and potassium budget in the soil-plant system in crop rotations under notill. Soil Till Res. 126:127-33.

Sainju UM, Whitehead WF, Singh BP (2005) Carbon accumulation in cotton, sorghum, and underlying soil as influenced by tillage, cover crops, and nitrogen fertilization. Plant Soil. 273:219-34.

Santos HG, Jacomine PKT, Anjos LHC, Oliveira VA, Oliveira JB, Coelho MR, Lumbreras JF, Cunha TJF (2013) Sistema brasileiro de classificação de solos. 3ạ. ed. Rio de Janeiro: Embrapa Solos.

Scivittaro WB, Muraoka T, Boaretto AE, Trivelin PCO (2004) Fate of nitrogen (15N) from velvet bean in the soil-plant system. Sci Agric. 61:210-5.

Scivittaro WB, Muraoka T, Boaretto AE, Trivelin PCO (2003) Transformações do nitrogênio proveniente de mucunapreta e uréia utilizados como adubo na cultura do milho. Pesq Agropec Bras. 38:1427-33.

Scivittaro WB, Muraoka T, Boaretto AE, Trivelin PCO (2000) Utilização de nitrogênio de adubos verdes e mineral pelo milho. Rev Bras Cienc Solo. 24:917-26.

Silva EC, Muraoka T, Alvarez Villanueva FC, Contreras Espinal FS (2009) Aproveitamento de nitrogênio pelo milho, em razão da adubação verde, nitrogenada e fosfatada. Pesq Agropec Bras. 44:118-27.

Silva EC, Muraoka T, Buzetti S, Espinal FSC, Trivelin PCO (2008) Utilização do nitrogênio da palha de milho e de adubos verdes pela cultura do milho. Rev Bras Cienc Solo. 32:2853-61.

Silva EC, Muraoka, T, Buzetti S, Trivelin PCO (2006a) Manejo de nitrogênio no milho em Latossolo Vermelho sob plantio direto com diferentes plantas de cobertura. Pesq Agropec Bras. 41:477-86

Silva EC, Muraoka T, Buzetti S, Veloso MEC, Trivelin PCO (2006b) Aproveitamento do nitrogênio (15N) da crotalária e do milheto pelo milho sob plantio direto em Latossolo Vermelho de Cerrado. Cienc Rural. 36:739-46.

Silva EC, Muraoka T, Monteiro ROC, Buzetti S (2007) Análise econômica da adubação nitrogenada no milho sob plantio direto em sucessão a plantas de cobertura em Latossolo Vermelho. Acta Sci Agron. 29:445-52.

Soil Survey Staff (2010) Keys to soil taxonomy. 11th ed. Washington, DC: United States Department of Agriculture, Natural Resources Conservation Service.

United States Department of Agriculture - USDA. Production, Supply and Distribution Online. Available at: http://www.usda.gov/wps/portal/usda/usdahome?navid= DATA_STATISTICS. Accessed December 15, 2015.

Varvel GE, Schpers JS, Francis DD (1997) Ability for in-season correction of nitrogen deficiency in corn using chlorophyll meters. Soil Sci Soc Am J. 61:1233-9.

Villas Bôas RL, Boaretto AE, Büll LT, Guerrini IA (1999) Parcelamento e largura da faixa de aplicação da uréia na recuperação do nitrogênio pela planta de milho. Sci Agric. 56:1177-84. 